\title{
EFEKTIFITAS PEMBELAJARAN BERBASIS LCD PROJECTOR DENGAN MODEL PEMBELAJARAN KONTEKSTUAL TERHADAP PRESTASI BELAJAR MAHASISWA
}

\author{
Nur Rohman ${ }^{1)}$, Dian Nurul Safitri ${ }^{2)}$ \\ ${ }^{1)}$ FPMIPA, IKIP PGRI Bojonegoro \\ email: nurrohmanspd83@yahoo.co.id \\ ${ }^{2)}$ FPMIPA, IKIP PGRI Bojonegoro \\ email: dian.nurul@ikippgribojonegoro.ac.id
}

\begin{abstract}
The purpose of this research is to know the effectiveness of LCD Projectorbased learning with contextual learning model on student achievement in the course of learning planning mathematics IKIP PGRI Bojonegoro. This research uses a quantitative approach and includes quasi experimental research because it is not possible to control all variables that affect the dependent variable. The population in this study is all students of second level of Mathematics Education department of IKIP PGRI Bojonegoro. The sample in this research is obtained by simple random sampling. The hypothesis proposed will be tested using the t-test. The result of this research is LCD projectorbased learning with contextual learning model more effective than conventional learning.
\end{abstract}

Keywords: Contextual learning model, learning achievement

\begin{abstract}
Abstrak : Tujuan penelitian ini adalah untuk mengetahui efektivitas pembelajaran berbasis LCD Projector dengan model pembelajaran kontekstual terhadap prestasi mahasiswa pada mata kuliah perencanaan pembelajaran matematika IKIP PGRI Bojonegoro. Penelitian ini menggunakan pendekatan kuantitatif dan termasuk penelitian eksperimental semu karena tidak memungkinkan untuk mengontrol semua variabel yang mempengaruhi variabel terikat. Populasi dalam penelitian ini adalah seluruh mahasiswa semester empat tingkat II Prodi Pendidikan Matematika FPMIPA IKIP PGRI Bojonegoro. Sampel dalam penelitian ini diperoleh dengan cara simple random sampling. Hipotesis yang dikemukakan akan diuji menggunakan uji-t. Hasil dari penelitian ini adalah pembelajaran berbasis LCD proyektor dengan model pembelajaran kontekstual lebih efektif dari pada pembelajaran konvensional.
\end{abstract}

Keywords: Model pembelajaran kontekstual, prestasi belajar

\section{PENDAHULUAN}

Pendidikan merupakan aspek penting bagi sumber daya manusia. Pendidikan juga merupakan salah satu alat yang bisa digunakan untuk membebaskan manusia dari kebodohan dan kemiskinan. Menurut Salahudin dalam Filsafat Pendidikan (2011:44), pendidikan merupakan proses mendidik, membina, mengendalikan, mengawasi, mempengaruhi dan mentransmisikan ilmu pengetahuan yang dilaksanakan oleh para pendidik kepada anak didik untuk membebaskan kebodohan, meningkatkan pengetahuan dan membentuk kepribadian yang lebih baik dan bermanfaat bagi kehidupan seharihari. Melalui pendidikan taraf hidup masyarakat dapat ditingkatkan.

Kecepatan kemajuan jaman menuntuk makin berkembangnya pendidikan. Hal ini lah yang harus dicermati bersama. Perkembangan 
Indonesia di bidang pendidikan dinilai sangat pelan apabila dibandingkan dengan Negara ASEAN lain, atau bahkan dunia Internasional. Menurut catatan TIMSS (Trends in International Mathematics and Science Study) tahun 2015, lembaga yang mengukur pendidikan dunia bahwa penguasaan matematika siswa grade 8 negara Indonesia di peringkat ke-45 dari 50 negara. Skor rata-rata yang diperoleh siswa-siswa Indonesia adalah 397. Skor ini masih jauh di bawah skor rata-rata internasional yaitu 500. Jika melihat hasil ini tentunya kita patut khawatir, ternyata dengan sumber daya alam yang begitu berlimpah masyarakat kita dinilai kurang mampu mengolah sumber daya alam tersebut.

Kondisi pendidikan Indonesia yang masih kurang ini menjadi tanggung jawab seluruh lapisan masyarakat. Baik pendidik, peserta didik, wali murid, atau masyarakat umum perlu menyadari pentingnya meningkatkan pendidikan. Yama (2015 : 103) menjelaskan peran pendidikan sebagaimana diamanatkan dalam UU tentang Sistem Pendidikan Nasional No 20 tahun 2003, Bab I, Pasal 1, Paragraf 1, bahwa "Pendidikan adalah kesadaran dan kesengajaan upaya untuk menciptkan suasana pembelajaran dan proses pembelajaran agar belajar peserta dapat secara aktif mengembangkan mereka potensi untuk memiliki: kekuatan spiritual melalui keyakinan agama; pengendalian diri, kepribadian, kecerdasan, akhlak mulia, dan keterampilan dibutuhkan oleh mereka sendiri, masyarakat, bangsa dan nyatanya". Dalam matematika sendiri banyak sekali ilmu atau kajian ilmu yang dipelajari mulai dari aljabar, kalkulus, statistik dan juga perencanaan pembelajaran. Salah satu kajian mata kuliah yang diajarkan dalam pembelajaran adalah mata kuliah perencanaan pembelajaran, pada pendidikan tinggi khususnya pada program studi matematika atau pendidikan matematika tentu saja mahasiswa akan dituntut untuk mempelajari mata kuliah perencanaan pembelajaran. Dari banyaknya perguruan tinggi yang ada, salah satu perguruan tinggi yang menyediakan program pendidikan matematika adalah IKIP PGRI Bojonegoro. Pada program studi pendidikan matematika di IKIP PGRI Bojonegoro salah satu mata kuliah yang harus ditempuh mahasiswa sebagai mata kuliah adalah perencanaan pembelajaran. Perencanaan pembelajaran merupakan salah satu mata kuliah wajib yang perlu ditempuh mahasiswa. Pada mata kuliah ini mahasiswa akan belajar bagaiman menyusun perangkat pembelajaran yang baik.

Pada tahun sebelumnya hasil nilai UTS dan UAS semester ganjil pada mata kuliah perencanaan pembelajaran terdapat rata-rata nilai rendah. Informasi yang didapat dalam wawancara dengan dosen yang mengajar mata kuliah perencanaan pembelajaran bahwa nilai rata-rata mahasiswa mendapatkan kurang dari 7,0 (B), itu artinya bahwa kebanyakan mahasiswa mendapatkan nilai rata-rata rendah. $(\mathrm{C})$.

Faktor yang mempengaruhi keberhasilan proses pembelajaran adalah model pembelajaran yang digunakan oleh dosen dan mahasiswa itu sendiri. Faktor lain dapat berupa penggunaan alat, sarana prasarana didalam sekolah kurikulum yang digunakan di sekolah. Faktor-faktor yang mempengaruhi prestasi belajar adalah faktor interen yang meliputi faktor jasmaniah (kesehatan dan cacat tubuh) dan faktor psikologi (intelegensi, perhatian, bakat, 
minat, motivasi, kematangan, dan kelelahan). Sedangkan faktor ekstern meliputi faktor keluarga (cara mendidik orang tua, relasi antar anggota keluarga, keadaan ekonomi keluarga keperluan keluarga, dan suasana rumah), faktor sekolah (metode mengajar, kurikulum, relasi guru dengan siswa, relasi siswa, disiplin sekolah dan alat pelajaran), dan faktor masyarakat (kegiatan siswa dengan dalam masyarakat, media masa, teman bergaul dan bentuk kehidupan masyarakat), Slameto (2010:54).

Faktor yang mempengaruhi keberhasilan proses pembelajaran adalah model pembelajaran yang digunakan oleh dosen dan mahasiswa itu sendiri. Faktor lain dapat berupa penggunaan alat, sarana prasarana didalam sekolah kurikulum yang digunakan di sekolah. Pada pembelajaran yang terjadi saat ini ternyata masih banyak guru maupun dosen yang masih menggunakan model pembelajaran langsung. Menurut Arends (dalam Trianto, 2007:29) metode pembelajaran langsung dirancang untuk menunjang proses belajar siswa yang berkaitan dengan pengetahuan deklaratif dan pengetahuan prosedural yang terstruktur dengan baik yang dapat diajarkan dengan pola kegiatan bertahap, selangkah demi selangkah. Metode pembelajaran ini menekankan pembelajaran yang didominasi oleh guru, jadi guru berperan penting dan dominan dalam proses pembelajaran (Riyanto, 2009:284).

Penggunaan

model

pembelajaran langsung dalam setiap materi pembelajaran tentu bukanlah hal yang baik. Hal inilah yang menjadi salah satu sebab rendahnya prestasi belajar peserta didik, baik siswa maupun mahasiswa. Untuk mengatasi masalah tersebut dalam penelitian ini mencoba untuk menawarkan penyelesaian melalui sebuah uji coba metode mengajar dengan menggunakan pembelajaran berbasis LCD Proyektor dengan model pembelajaran kontekstual. Media pembelajaran yang baik adalah media yang dapat mengkonkretkan materi yang akan dipelajari sehingga dapat dipahami siswa dengan mudah. Menurut Utami (2017: 52) LCD Proyektor merupakan alat yang dapat memproyeksikan trasparansi gambar atau tulisan ke arah layar yang disediakan. Pembelajaran menggunakan media LCD Projector merupakan proses pembelajaran yang menggunakan LCD Proyektor sebagai media pembelajaran. LCD Proyektor saat ini banyak dipakai sebagai proyeksi layar komputer maupun Note Book atau Laptop. Laptop yang dipadukan dengan Proyektor dapat dijadikan media pembelajaran yang cukup menarik. Proses pembelajaran dengan menggunakan media pembelajaran LCD proyektor dilakukan dengan menggunakan Laptop atau Note Book yang telah didesain dan dirancang sesuai dengan materi pembelajaran. LCD proyektor dapat menampilkan semua program pembelajaran yang telah didesain dan disusun didalam Laptop ke layar yang lebarnya kurang lebih 2 X 2 meter. Dengan demikian media pembelajaran LCD proyektor ini sangat mendukung digunakan untuk kelas besar dengan jumlah peserta didik yang banyak. Dalam penelitian ini program pembelajaran yang digunakan adalah dengan menggunakan program Power Point yang didesain dengan langkah langkah sebagai berikut: 1) Menyiapkan Power Point sesuai dengan isi materi pembelajaran yang akan diberikan, 2) Menyiapkan LCD proyektor, 3) Mengatur kesiapan peserta didik, 4) Membuka proses pembelajaran, 5) Penyajian atau presentasi oleh guru 
sesuai dengan urutan yang sudah dirancang, 6) Membuat kesimpulan atas materi yang diberikan, 7) Penutup

Perubahan paradigma

pembelajaran ke arah keaktifan mahasiswa menuntut dosen untuk dapat mengemas pembelajaran dengan lebih efektif. Pembelajaran tersebut bisa dilakukan melalui pembelajaran aktif dengan pembelajaran kontekstual (contextual teaching and learning, CTL). Menurut Sanjaya (2011:255) CTL adalah suatu strategi pembelajaran yang menekankan kepada proses keterlibatan siswa secara penuh untuk dapat menemukan materi yang dipelajari dan menghubungkannya dengan situasi kehidupan nyata sehingga mendorong siswa untuk dapat menerapkannya dalam kehidupan mereka.

Untuk mencapai kompetensi dengan menggunakan pembelajaran kontekstual, langkah-langkah yang perlu dilakukan adalah sebagai berikut: 1) Guru men-jelaskan kompetensi yang harus dicapai serta manfaat dari proses pembelajaran dan pentingnya materi pelajaran yang akan dicapai, 2) Guru menjelaskan prosedur pembelajaran kontekstual, 3) Guru melakukan tanya jawab sekitar tugas yang harus dikerjakan oleh setiap siswa. Selanjutnya pembelajaran dikaitkan dengan kegiatan sehari-hari mahasiswa. Kegiatan ini dilakukan dengan langkah sebagai berikut: 4) Siswa melakukan observasi sesuai dengan pembagian tugas kelompok, 5) Siswa mencatat hasil observasinya berkaitan dengan materi yang telah ditentukan sebelumnya. Pembelajaran kembali dilaksanakan di dalam kelas dengan: 6) siswa mendiskusikan hasil temuan mereka sesuai dengan kelompoknya masingmasing, 7) siswa melaporkan hasil diskusi, 8) setiap kelompok menjawab setiap pertanyaan yang diajukan oleh kelompok yang lain, 9) dengan bantuan guru siswa menyimpulkan hasil observasi sesuai dengan indikator hasil belajar yang harus dicapai.

Tujuan dilakukan penelitian ini adalah untuk mengetahui keefektifan pembelajaran berbasis LCD projector dengan model pembelajaran kontekstual dalam menghasilkan prestasi belajar yang lebih baik pada mata kuliah perencanaan pembelajaran mahasiswa IKIP PGRI Bojonegoro.

\section{METODE PENELITIAN}

Penelitian ini merupakan penelitian eksperimental. Variabel terikat dalam penelitian ini adalah prestasi belajar mahasiswa pada mata kuliah Perencanaan pembelajaran dan variabel bebas dalam penelitian ini adalah model pembelajaran.

Metode dalam penelitian dibagi menjadi tiga tahap yang berlangsung selama satu tahun. Tahap pertama adalah penentuan sampel penelitian dan melakukan uji keseimbangan dengan data nilai UAS semester tiga tingkat II Prodi Pendidikan Matematika IKIP PGRI Bojonegoro. Tahap kedua penyusunan perangkat pembelajaran dan soal untuk memilih format tes yang paling baik (reliabel dan valid). Tahap ketiga untuk meneliti efektivitas pembelajaran berbasis LCD Proyektor dengan model pembelajaran kontekstual pada mata kuliah perencanaan pembelejaran terhadap prestasi belajar mahasiswa pendidikan matematika.

Penelitian ini dilaksanakan di IKIP PGRI Bojonegoro pada mahasiswa semester empat tingkat II. Teknik pengumpulan data pada penelitian ini menggunakan teknik dokumentasi dan tes. Teknik dokumentasi digunakan untuk menggambil data UAS mahasiswa 
semester tiga tingkat II sebagai bahan untuk uji keseimbangan kelas sampel sebelum dikenai perlakuan. Teknik tes pada penelitian ini menggunakan tes prestasi belajar mahasiswa pada mata kuliah perencanaan pembelajaran.

Instrumen yang digunakan pada penelitian ini berupa dokumen hasil UAS mahasiswa semester tiga tingkat II, dan soal tes prestasi belajar berkaitan dengan perencanaan pembelajaran. Data nilai UAS mahasiswa semester tiga tingkat II untuk uji keseimbangan. Soal tes prestasi belajar digunakan untuk mengambil data kemampuan mahasiswa dalam mata kuliah perencanaan pembelajaran.

Penelitian ini menggunakan teknik uji-t, yaitu suatu desain penelitian yang digunakan untuk meneliti ada atau tidaknya perbedaan rerata pada dua populasi dari perlakuan model pembelajaran yang berbeda terhadap prestasi belajar mahasiswa. Uji prasyarat dalam penelitian ini menggunakan uji normalitas dengan metode Lilliefors karena datanya berupa data tunggal dan uji homogenitas dengan uji $F$. Uji prasyarat digunakan untuk uji keseimbangan dan uji hipotesis.

\section{HASIL DAN PEMBAHASAN}

Penelitian ini diawali dengan uji keseimbangan pada kedua kelas kontrol dan kelas eksperimen. Uji keseimbangan dilakukan dengan uji-t. Sebelum masuk uji keseimbangan terlebih dahulu data yang didapat diuji normalitas dengan menggunakan metode Liliefors dan uji homogenitas dengan Uji $F$. Setelah dilakukan perhitungan didapat nilai sebagai berikut:

\begin{tabular}{cccc}
\hline Uji & $\begin{array}{c}\text { Nilai } \\
\text { Tabel }\end{array}$ & $\begin{array}{c}\text { Hasil } \\
\text { Observasi }\end{array}$ & Ket. \\
\hline $\begin{array}{c}\text { Normalitas } \\
\text { Kontrol }\end{array}$ & 0,1292 & 0,1262 & Normal \\
\hline
\end{tabular}

\begin{tabular}{cccc}
\hline $\begin{array}{c}\text { Normalitas } \\
\text { Eksperimen }\end{array}$ & 0,1279 & 0,0874 & Normal \\
\hline Homogenitas & 1,74 & 1,082 & Homogen \\
\hline
\end{tabular}

Dari tabel di atas diketahui bahwa data awal baik dari kelas kontrol maupun kelas eksperimen masing-masing berdistribusi normal dan juga memiliki variansi yang homogen.

Setelah data dinyatakan normal dan homogen maka selanjutnya data dianalisi keseimbangannya dengan menggunakan uji- $t$ setelah dilakukan perhitungan didapat hasil bahwa nilai $t_{o b s}$ $=0,0615$ dan $t_{\text {tabel }}=1,6710$. Hasil ini menunjukkan bahwa tidak ada perbedaan kondisi awal antara kelas kontrol yang diajar dengan menggunakan pembelajaran konvensional dan kelas eksperimen yang diajar menggunakan model pembelajaran kontekstual dengan LCD Proyektor. Uji keseimbangan dilakukan untuk mengetahui bahwa sebelum diberikan perlakukan dengan model pembelajaran yang berbeda kelas kontrol dan kelas eksperimen memiliki kemampuan awal yang sama. Hal ini dilakukan untuk memastikan bahwa hasil yang diperoleh adalah dikarenakan adanya perbedaan perlakuan dengan model pembelajaran yang berbeda.

Hipotesis dalam penelitian ini menyatakan bahwa pembelajaran berbasis LCD proyektor dengan model pembelajaran kontekstual dapat memberikan hasil prestasi lebih baik daripada pembelajaran konvensional. Sebelum dilakukan analisis untuk membuktikan hipotesis terlebih dahulu dilakukan uji prayarat uji- $t$ yaitu uji normalitas dan homogenitas, dengan langkah seperti pada uji prasyarat pada uji keseimbangan. Hasil yang diperoleh adalah sebagai berikut: 


\begin{tabular}{cccc}
\hline Uji & $\begin{array}{c}\text { Nilai } \\
\text { Tabel }\end{array}$ & $\begin{array}{c}\text { Hasil } \\
\text { Observasi }\end{array}$ & Ket. \\
\hline $\begin{array}{c}\text { Normalitas } \\
\text { Kontrol }\end{array}$ & 0,1292 & 0,1143 & Normal \\
\hline $\begin{array}{c}\text { Normalitas } \\
\text { Eksperimen }\end{array}$ & 0,1279 & 0,0987 & Normal \\
\hline Homogenitas & 1,74 & 1,64 & Homogen \\
\hline
\end{tabular}

Dengan melihat tabel tersebut maka dapat dilihat bahwa data prestasi belajar di kelas konrol dan eksperimen berdistribusi normal, dan homogen.

Berdasarkan hasil uji $t$ satu ekor diperoleh nilai $t_{o b s}=4,1264$ dan $t_{\text {tabel }}=$ 1,6710. Dari hasil tersebut dapat disimpulakn bahwa pembelajaran berbasis LCD proyektor dengan model pembelajaran kontekstual dapat memberikan hasil prestasi lebih baik daripada pembelajaran konvensional.

Keberhasilan proses belajar mengajar dalam mencapai tujuan pengajaran dapat dilihat dari prestasi belajar peserta didik. Banyak faktor yang mempengaruhi prestasi belajar, di antaranya adalah model pembelajaran dan media pembelajaran yang dipakai dalam proses belajar mahasiswa. Penggunaan model pembelajaran yang menarik dapat memberikan pengaruh terhadap keberhasilan dosen dalam mengajar. Model pembelajaran dan media pembelajaran merupakan bentuk pembelajaran dimana mahasiswa secara aktif mengontruksi pengetahuan mereka sendiri. Mahasiswa akan lebih mudah memahami materi dengan bantuan media pembelajaran serta mahasiswa dapat menemukan dan memahami konsep-konsep yang sulit dalam pelajaran apabila mereka dapat saling mendiskusikan masalah tersebut dengan temannya. Model pembelajaran kontekstual adalah merupakan model pembelajaran yang menekankan kepada proses keterlibatan mahasiswa secara penuh untuk dapat menemukan materi yang dipelajari dan menghubungkannya dengan situasi kehidupan nyata sehingga mendorong siswa untuk dapat menerapkannya dalam kehidupan seharihari. Selain itu pembelajaran berbasis LCD proyektor juga membantu mahasiswa untuk lebih aktif dan giat dalam mengikuti pembelajaran dikelas sebab dengan bantuan LCD proyektor pembelajaran lebih bermakna bagi mahasiswa.

Keefektifan penggunaan media pembelajaran berbasis LCD proyektor dengan model pembelajaran kontekstual dalam pembelajaran terjadi dikarenakan sebelum dilakukan pembelajaran, mahasiswa diberikan masukan, motivasi terkait dengan pembelajaran yang akan berlangsung sehingga mahasiswa merasa lebih nyaman. Dengan menggunakan media pembelajaran berbasis LCD proyektor, tentu bukan saja dapat membantu atau mempermudah dan mengefektifkan proses pembelajaran mengajar, akan tetapi juga dapat membuat proses pembelajaran menjadi lebih menyenangkan dan menarik.

$$
\text { Penggunaan }
$$
media pembelajaran berbasis LCD proyektor ini dapat memperkecil kegagalan mahasiswa yang biasa terjadi dalam proses pembelajaran mengajar. Kegagalan-kegagalan tersebut dapat dihindari, jika dosen dapat menggunakan pembelajaran dengan memanfaatkan berbagai media sebagai alternatif yaitu media pembelajaran berbasis LCD proyektor. Selain itu dengan Perkembangan teknologi yang begitu cepat, media pembelajaran berbasis LCD proyektor sangat sesuai untuk diterapkan. Pada pembelajaran dengan model pembelajaran ini dosen bisa mengatasi pelebaran materi sehingga lebih terfokus, karena materi telah disipkan sebelumnya. LCD 
proyektor juga mampu menampilkan gambar lebih nyata dari pada gambar manual, selain itu melalui LCD proyekor juga mampu menampilkan gambar bergerak. Gambar bergerak sangat membantu dalam penerimaan mahasiswa pada materi pembelajaran. Dengan kata lain LCD proyektor mampu membuat visualisasi dari pemikiran dosen, sehingga lebih mudah di mengerti mahasiswa.

Selain media pembelajaran dengan menggunakan LCD proyektor, pembelajaran dalam penelitian ini juga menggunakan pembelajaran kontekstual. Pembelajaran kontekstual adalah pembelajaran yang mengkaitkan pembelajaran dengan kehidupan seharihari mahasiswa. Pada pembelajaran kontekstual mahasiswa dituntut untuk mampu mengkaitkan materi yang mereka dapat dengan kehidupan seharihari. Dengan mengaitkan inilah materi bisa terserap lebih optimal. Mahasiswa yang diajar menggukan pembelajaran kontekstual akan mengalami pengalaman belajar lebih banyak, hal ini dikarenakan dalam kehidupan sehariharipun mereka juga belajar dari ilmu atau materi yang mereka dapat di sekolah atau kampus. Selain itu ketika mahasiswa mendapatkan materi di sekolah mereka langsung dapat menerapkan materi tersebut dalam kehidupan sehari-hari.

Model pembelajaran dan media pembelajaran merupakan bentuk pembelajaran dimana mahasiswa secara aktif mengontruksi pengetahuan mereka sendiri. Mahasiswa akan lebih mudah memahami materi dengan bantuan media pembelajaran serta mahasiswa dapat menemukan dan memahami konsep-konsep yang sulit dalam pelajaran apabila mereka dapat saling mendiskusikan masalah tersebut dengan temannya. Model pembelajaran kontekstual adalah merupakan model pembelajaran yang menekankan kepada proses keterlibatan mahasiswa secara penuh untuk dapat menemukan materi yang dipelajari dan menghubungkannya dengan situasi kehidupan nyata sehingga mendorong siswa untuk dapat menerapkannya dalam kehidupan seharihari. Selain itu pembelajaran berbasis LCD proyektor juga membantu mahasiswa untuk lebih aktif dan giat dalam mengikuti pembelajaran dikelas sebab dengan bantuan LCD proyektor pembelajaran lebih bermakna bagi mahasiswa. Hal ini sesuai dengan penelitian yang dilakukan oleh Marwanto (2014: 592) yang menyatakan bahwa pembelajaran dengan menggunakan pembelajaran kontekstual mampu meningkatkan prestasi belajar. Penelitian yang dilakukan Amin (2012: 103) yang menyatakan bahwa pembelajaran dengan pembelajaran kontekstual memberikan prestasi belajar yang lebih baik daripada pembelajaran konvensional. Selain itu penelitian yang dilakukan oleh Hariadi (2017:100) yang menyebutkan bahwa ada pengaruh positif penggunaan LCD proyektor terhadap prestasi belajar mahasiswa.

\begin{tabular}{lr}
\multicolumn{2}{c}{ Kombinasi pembelajaran } \\
dengan menggunakan & model \\
pembelajaran kontekstual dan & LCD \\
proyektor mampu menghasilkan prestasi \\
belajar yang maksimal. Pada \\
pembelajaran ini mahasiswa disajikan
\end{tabular}
materi dengan penampilan yang menarik dan mereka tahu penerapan materi yang mereka dapat. Dengan mengetahui fungsi dari belajar ilmu tertentu akan turut memotivasi mahasiswa untuk terus meningkatkan prestasi belajar sehingga prestasi belajar akan terus meningkat. Sajian materi yang menarik akan 
membuat mahasiswa terhindar dari kebosanan dan kejenuhan dalam belajar.

Di dalam penelitian ini telah dibuktikan bahwa pembelajaran dengan menggunakan model pembelajaran kontekstual dengan dikombinasikan menggunakan media pembelajaran LCD proyekor telah mampu menghasilkan prestasi belajar yang lebih baik jika dibandingkan dengan pembelajaran menggunakan pembelajaran langsung.

\section{SIMPULAN}

Dari hasil analisis uji hipotesis yang telah diuraikan di atas dapat disimpulkan bahwa: pembelajaran berbasis LCD proyektor dengan model pembelajaran kontekstual lebih efektif memberikan prestasi belajar mahasiswa IKIP PGRI Bojonegoro dibanding dengan pembelajaran konvensional pada mata kuliah perencanaan pembelajaran tahun akademik 2017/2018.

\section{DAFTAR RUJUKAN}

Amin, A. K. (2012). Eksperimentasi Pembelajaran Pendekatan Contextual Teaching and Learning (CTL) dengan Memasukkan Unsur-Unsur Quantum Learning pada Sub Pokok Bahasan Bangun Ruang Sisi Datar Ditinjau dari Motivasi Belajar Siswa Kelas VIII SMP Negeri Se Kabupaten Bojonegoro. Surakarta: Universitas Sebelas Maret

Hariadi, S. (2017). Pengaruh Penggunaan Media Pembelajaran LCD Proyektor dan Motivasi Belajar Terhadap Prestasi Belajar Mata Pelajaran IPS. Jurnal
Penelitian dan Pendidikan IPS (JPPI), Vol. 11, No. 1, 100-110.

Krisiandi. (2016, Desember 15). Daya Imajinasi Siswa Lemah. Retrieved from Kompas.com: https://nasional.kompas.com/r ead/2016/12/1523091361/day a.imajinasi.siswa.lemah

Marwanto, R., Suhartono, \& Joharman. (2014). Penerapan Model Contextual Teaching and Learning (CTL) dalam Peningkatan Pembelajaran Bangun Ruang Siswa Kelas V SD Negeri 2 Pejagatan Tahun Ajaran 2013/2014. Kalam Cendikia, Vol. 3, No. 6.1, 592-596.

Riyanto, Y. (2009). Paradigma Baru Pembelajaran : Sebagai Referensi bagi Pendidik dalam Implementasi Pembelajaran yang Efektif dan Berkualitas. Jakarta : Kencana.

Salahudin, A. (2011). Filsafat Pendidikan. Bandung: Pustaka Setia.

Sanjaya, W. (2011). Strategi Pembelajaran Berorientasi Standar Proses Pendidikan. Jakarta : Kencana.

Slameto. (2010). Belajar Dan Faktor-Faktor Yang Mempengaruhinya. Jakarta : PT. Rineka Cipta.

Trianto. (2007). Model-model Pembelajaran Inovatif Berorientasi Konstruktivistik. Jakarta: Prestasi Pustaka.

Utami, Y. (2017). Pengaruh Pemanfaatan Media Pembelajaran Proyektor LCD Menggunakan Program Power Point Terhadap hasil Belajar Siswa dalam Menentukan Volume Kubus 
dan Balok pada Bangun

Ruang. Jurnal Mantik

Penusa, Vol. 1, No. 1, 52-58.

Yama, D. (2015). The Revitalization

Policy Of Character-

Education In Terms Of Strengthening The Concept Of Nationalism. Directorate
General the National Unity and Politics Agency (Kesbangpol), the Ministry Of Home Affairs International Journal of Education, Vol. 8, No. 2, 103110. 
88 JURNAL PENDIDIKAN EDUTAMA, Vol 5, No. 2, Juli 2018 